\title{
Did The Program Kampung Iklim Lead Farmers to Implement More Adaptation Startegies? Case Study of Rice Farmers in Sleman Regency
}

\author{
Moh. Wahyudi Priyanto ${ }^{1}$, Jangkung Handoyo Mulyo ${ }^{2}$, Irham ${ }^{3}$ \\ ${ }^{1}$ Agricultural Economics, Faculty of Agriculture, \\ Universitas Gadjah Mada \\ 2,3 Departement of Agricultural Socioeconomics, Faculty of Agriculture, Universitas \\ Gadjah Mada \\ Jl. Flora No. 1 Bulaksumur, Yogyakarta \\ Pmwahyudi26@gmail.com
}

Submitted : 29 Juni 2020 ; Revised : 31 August 2020; Accepted : 19 November 2020

\begin{abstract}
The negative impacts of climate change caused many losses for farmers. One solution to minimize losses is to implement a climate change adaptation strategy. The Indonesian government established a program called the Program Kampung Iklim/Proklim in 2012 which aims to increase awareness of climate change and the capacity to implement community adaptation strategies. This study aimed to determine the effect of the Proklim on the implementation of climate change adaptation strategy by farmers. The study was conducted in Proklim and nonProklim locations. By implementing the simple random sampling method, it was obtained 112 samples divided into 56 farmers from each Proklim and non-Proklim location. The results showed that farming experience, land area, membership in farmers group, access to weather information, awareness towards climate change and perceptions towards climate change risks are associated with more practice of adaptation strategy. The results also showed that the implementation of adaptation strategy was influenced by the Proklim location, so that the farmers involved in the program locations applied more climate change adaptation strategy than the farmers in non-program locations. The authors recommend that Proklim needs to be applied in many locations, especially areas that are vulnerable to climate change, so farmers can improve the implementation of climate change adaptation strategies.
\end{abstract}

Keywords: adaptation strategy, climate change, proklim

How to cite : Priyanto, M.W., Mulyo, J.H., and Irham. Did The Program Kampung Iklim Lead Farmers to Implement More Adaptation Startegies? Case Study of Rice Farmers in Sleman Regency. Agro Ekonomi 31(2), xx-xx

\section{INTRODUCTION}

Unnatural changes in climate indicators such as unpredictable rainfall, shifting seasons, and increasing environmental temperatures, cause concern for the phenomenon of climate change (WMO, 2017). Global land and sea surface temperature trends in 18802010 have reported an increase in average temperature of $0.85^{\circ} \mathrm{C}$, with a 
range between $0.65^{\circ} \mathrm{C}$ to $1.06^{\circ} \mathrm{C}$ (IPCC, 2014). Indonesia is one of the countries with the highest levels of greenhouse gas emission that is very vulnerable to the impacts caused by climate change (Measey, 2010), and one of the most vulnerable sectors to this is the agricultural sector, especially grains and vegetables (Bacha et al., 2018). Climate change indirectly causes agricultural land to dry up, land management increasingly difficult, and a decrease in the volume of water sources (Irham et al., 2018), which then has an impact on decreasing production and can cause crop failure.

The negative impacts of climate change on crop yields can be minimized by implementing adaptation strategies that are technically appropriate, sociocultural, and economically feasible, so that farmers can still maintain their main livelihood (Waibel et al., 2017; Widada et al., 2014). Some of the adaptation strategies adopted by farmers are crop rotation, soil fragmentation, making bore well, using short duration rice varieties, reduce soil acidity by adding calcium fertilizers (ameliorant), and others (Aldrian et al., 2011; Fadina \& Barjolle, 2018; Muslim, 2013). Implementing climate change adaptation strategies can provide benefits in the form of increased productivity and incomes of farmers (Abid et al., 2016; Ali \& Erenstein, 2017).

The government also participated to improve the implementation of community adaptation strategies to climate change by establishing a program called the Program Kampung Iklim in 2012. Based on the Ministry of Environment and Forestry
(Kementerian Lingkungan Hidup dan Kehutanan) No. P. 84/ MENLHKSETJEN/ KUM.1/ 11/ 2016, Program Kampung Iklim or Proklim is a national scope program managed by the Ministry of Environment and Forestry to increase the involvement of the community and stakeholders in strengthening the capacity of adaptation to the effects of climate change and reducing greenhouse gas emissions. Proklim gives recognition to all adaptation and mitigation efforts made by the community following regional conditions to improve local welfare. Through the implementation of adaptation strategies, communities from Proklim locations have the resistance to face drought, floods, crop failure, and are able to increase food security (Gunawati \& Rejekiningsih, 2020; Muttaqin et al., 2019). In addition, there are other programs that aim to improve the implementation of adaptation strategies, namely the Climate Smart Village (CSV) program, one of which is carried out in Nepal (Aggarwal et al., 2018; Khanal et al., 2019).

In formulating policies related to the adoption of adaptation strategies, policy makers must pay attention to the factors that enhance the adoption of adaptation strategies (Niles et al., 2015). A lot of researches have obtained results that farmer education, farming experience, land area, land status, experience of crop failure, number of family members, membership in farmers group, and weather information influence the implementation of climate change adaptation strategies (Abid et al., 2016; Ali \& Erenstein, 2017; Fadina \& Barjolle, 2018; Fagariba et al., 2018; Gc 
\& Yeo, 2019; Trinh et al., 2018). The adoption of adaptation strategies is also influenced by farmers 'awareness of the phenomenon of climate change (Hasan \& Kumar, 2019) and perceptions of risks posed by climate change to farmers' cultivation (Azadi et al., 2019).

Related to the existence of the program, previous research only focused on the adaptation strategy activities, the distribution of the community implementing the adaptation strategy and the benefits of the strategy application for the people who were in the program location (Khanal et al., 2019; Muttaqin et al., 2019). Previous research was conducted without involving non-program locations. The novelty of this research is that it investigates the effect of the Program Kampung Iklim (Proklim) on the implementation of climate change adaptation strategies by farmers. The research is important to know whether the existence of a Proklim can improve the implementation of adaptation strategies by farmers, so the results are expected to be used as an evaluation for future policies.

\section{METHODS}

Table 1. Location of the study

\begin{tabular}{|c|c|c|c|c|}
\hline \multirow{2}{*}{ Sub-regency } & \multirow{2}{*}{ Village/ Hamlet } & \multirow{2}{*}{ Population } & \multicolumn{2}{|c|}{ Sample } \\
\hline & & & Proklim & Non-proklim \\
\hline \multirow[t]{3}{*}{ Ngaglik } & Sariharjo & 621 & & \\
\hline & - Wonorejo & & 16 & - \\
\hline & - Karangmloko & & . & 16 \\
\hline \multirow[t]{3}{*}{ Sleman } & Pandowoharjo & 851 & & \\
\hline & - Karangtanjung & & 20 & - \\
\hline & - Karangasem & & - & 20 \\
\hline \multirow[t]{4}{*}{ Moyudan } & Sumberagung & 1,524 & & \\
\hline & - Pendulan & & 20 & - \\
\hline & - Kaliduren II & & - & 20 \\
\hline & Total & 2,996 & 56 & 56 \\
\hline
\end{tabular}

Sleman Regency was chosen purposively as a research location. The first reason, Sleman Regency shows a decreasing trend of rice productivity and an increase in climate indicators, namely maximum rainfall, wind speed, minimum temperature and maximum temperature based on 2008-2017 data (BPS Sleman, 2019). The second reason, there are 9 hamlets registered as Proklim participants spread across 6 sub-regency based on information from The Department of Environment and Forestry of Sleman Regency. This research was conducted in 3 villages that have Proklim hamlets which had won Proklim competitions at the national level, namely Wonorejo Hamlet, Ngaglik Sub-Regency (2018), Karangtanjung Hamlet, Sleman SubRegency (2018), and Pendulan Hamlet, Moyudan Sub-Regency (2016). Then the non-Proklim hamlet was selected from the same sub-regency and village as a comparison of the Proklim location (Table 1).The simple random sampling was used suggesting a total sample of 112 farmers from Proklim and nonProklim locations with the distribution shown in Table 1. The total population of farmers in the study location was 2,996 farmers. 
Based on the results, there were 14 at least 1 adaptation strategy, so the farmers (12.5\%) who did not implement bound of error of the number of samples the adaptation strategy and there were was shown by the following calculation 98 farmers (87.5\%) who implemented (Nazir, 2017),

$$
\begin{gathered}
V(\bar{p})=\frac{\bar{p}(1-\bar{p})}{n-1}\left(\frac{N-n}{N}\right) \\
V(\bar{p})=\frac{0.875(0.125)}{112-1}\left(\frac{2,996-112}{2,996}\right) \\
V(\bar{p})=0.000949
\end{gathered}
$$

Notes:

$V(\bar{p}) \quad$ : Estimates of variance

$\bar{p} \quad$ : Percentage of farmers implementing at least 1 adaptation strategy

$(1-\bar{p}):$ Percentage of farmers who don't implement adaptation strategies

$n \quad:$ Number of Samples

$N \quad$ : Total population

Obtained bound of error values:

$$
B=\sqrt{V(\bar{p})}=0.0308
$$

The value of 0.0308 or $3.08 \%$ is the error limit or the maximum error limit in determining 112 farmers samples from a population of 2,996 .

\section{Tobit regression model}

Tobit regression analysis is used to determine the effect of Proklim on the number of climate change adaptation strategies implemented by farmers. Tobit regression analysis was developed by Tobin to analyze the factors influence the dependent variable that is censored at the lower or upper threshold, or both. The dependent variable in this study is censored at a low threshold because it has a value of 0 (Farmers who don't implement adaptation strategies) at the upper threshold because the maximum adaptation strategy studied was 4 strategies. Research with censored dependent variables will show inconsistent estimation results when analyzed using OLS regression with the least squares estimation approach (Greene, 2012). The tobit regression model is shown by the following model,

$$
\begin{gathered}
Y=\alpha+\beta_{1} X_{1}+\beta_{2} X_{2}+\beta_{3} X_{3}+\beta_{4} X_{4}+\beta_{5} X_{5}+ \\
\beta_{6} X_{6}+\beta_{7} X_{7}+\beta_{8} X_{8}+\beta_{9} X_{9}+\beta_{10} X_{10}+\beta_{11} X_{11}+ \\
\varepsilon
\end{gathered}
$$

Where the dependent variable $Y$ is the number of adaptation strategies; $\mathrm{X}_{1}-\mathrm{X}_{11}$ are the independent variables namely $X_{1}$ is Proklim, $X_{2}$ is farmer education, $X_{3}$ is farming experience, $X_{4}$ is land area, $X_{5}$ is own land, $X_{6}$ is rental land, $X_{7}$ is harvest failure, $X_{8}$ is membership in farmers group, $X_{9}$ is weather information, $X_{10}$ is awareness of climate change, and $X_{11}$ is perception of the risks of climate change; $\alpha$ is the intercept or the model constant; $\beta_{1}-\beta_{11}$ is regression coefficient; $\varepsilon$ is error term.

Table 2 shows the variables using tobit regression model and the 
Table 2. Definition of variables used in the tobit model

\begin{tabular}{|c|c|}
\hline Variable & Variable definition \\
\hline \multicolumn{2}{|l|}{ Dependent variable } \\
\hline $\begin{array}{l}\text { Climate change } \\
\text { adaptation strategies }\end{array}$ & $\begin{array}{l}\text { Number of adaptation strategies implemented by farmers, i.e., } \\
1 \text { to } 4 \text { strategies. The adaptation strategies studied were crop } \\
\text { rotation, use of bore well, use of short duration rice varieties, } \\
\text { and use calcium fertilizers / ameliorant. }\end{array}$ \\
\hline \multicolumn{2}{|l|}{ Independent variable } \\
\hline & omes from a proklı \\
\hline tion & \\
\hline ence & of $f_{2}$ \\
\hline Lan & rs for rice cultiva \\
\hline & \\
\hline & \\
\hline Sharecropped land & $\begin{array}{l}1 \text { if farmers cultivate rice on the sharecropped land, } 0 \text { if } \\
\text { otherwise }\end{array}$ \\
\hline Harve & rs have experienced $100 \%$ cro \\
\hline $\begin{array}{l}\text { Membership in farmers } \\
\text { group }\end{array}$ & 1 if farmers are members of farmers group, 0 if otherwise \\
\hline Weather information & \\
\hline $\begin{array}{l}\text { Awareness of climate } \\
\text { change }\end{array}$ & $\begin{array}{l}\text { Farmers' awareness of the phenomenon of climate change in } \\
\% .\end{array}$ \\
\hline $\begin{array}{l}\text { Perception of the risks of } \\
\text { climate change }\end{array}$ & armers' perceptions of climate change risk in $\%$. \\
\hline \multicolumn{2}{|c|}{ 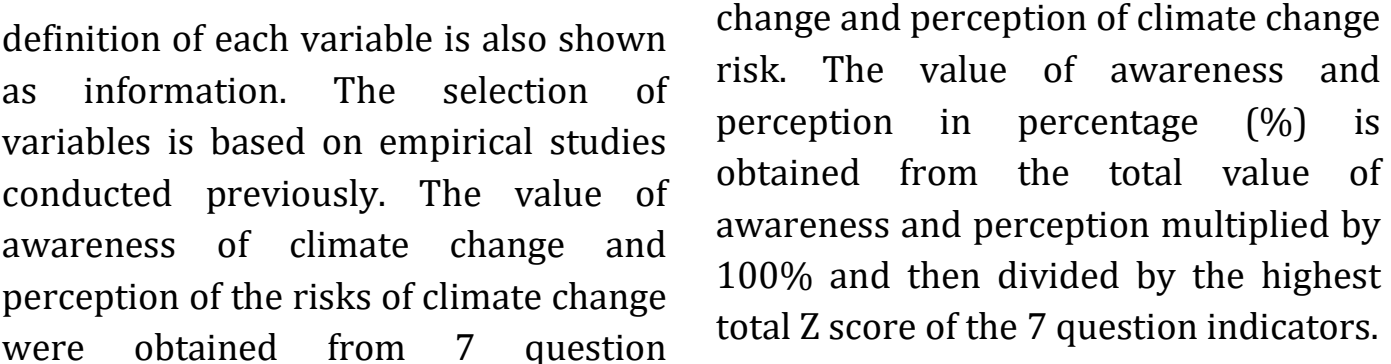 } \\
\hline
\end{tabular}

indicators. The indicators consist of temperature, rainfall, wind speed, and unpredictable seasonal changes, as well as their impact if an increase occurs. The Likert scale is used to obtain farmers' answers to indicators. The Likert scale cannot be summed up because it's an ordinal scale. The scores on the question indicator can be summed up if converted into a ratio scale. Therefore, the $\mathrm{Z}$ distribution approach is carried out to fulfill it (Sappaile, 2007). The question indicators are converted into a $\mathrm{Z}$ score so that it can be summed up to obtain the value of awareness of climate

\section{RESULTS AND DISCUSSION Farmers' climate change adaptation strategies}

The number of adaptation strategies implemented by farmers is shown in Table 3. There were 98 farmers $(87.5 \%)$ implementing more than one adaptation strategy. From 56 farmers from Proklim and 56 nonProklim farmers, there were $12.5 \%$ farmers who did not implement the adaptation strategy, consisting of 5.4\% Proklim farmers and 7.1\% non-Proklim farmers. This shows that the number of 
Table 3. Distribution of Proklim and non-Proklim farmers based on the number and average implementation of adaptation strategies

\begin{tabular}{|c|c|c|c|c|c|c|}
\hline \multirow{2}{*}{ Location } & \multicolumn{5}{|c|}{$\begin{array}{l}\text { Percentage of farmers based on number of } \\
\text { adaptation strategies implemented (\%) }\end{array}$} & \multirow{2}{*}{$\begin{array}{c}\text { Average number of } \\
\text { adaptation } \\
\text { strategies } \\
\text { (Adaptation } \\
\text { strategy) } \\
\end{array}$} \\
\hline & 0 & 1 & 2 & 3 & 4 & \\
\hline Proklim (56) & 5.4 & 4.5 & 28.6 & 10.7 & 0.9 & 1.9 \\
\hline Non-proklim (56) & 7.1 & 10.7 & 23.2 & 6.3 & 2.7 & 1.7 \\
\hline Difference & -1.7 & -6.2 & 5.4 & 4.4 & -1.8 & 0.2 \\
\hline
\end{tabular}

Source: Analysis of primary data, 2020

farmers who did not implement adaptation strategies. Farmers with the adaptation strategies from Proklim implementation of 4 adaptation locations was less than from non- strategies had the highest average land Proklim locations. Farmers from area, awareness, and perception of 0.85 Proklim locations mostly applied 2 and $\mathrm{Ha}, 68.24 \%$, and 85.76\%, respectively. 3 adaptation strategies, while farmers Farmers without implementation had from non-Proklim locations mostly the lowest average land area and applied 1 and 4 adaptation strategies. perception of 0.1 ha and $67.24 \%$,

Farmers' capital and knowledge respectively. Farmers with the lowest about climate change were several average awareness (53.2\%) mostly factors affecting the number of implemented 1 adaptation strategy.

Table 4. Results of tobit regression analysis on the factors that influence the number of climate change adaptation strategies

\begin{tabular}{|c|c|c|c|c|}
\hline Variable & $\begin{array}{l}\text { Expected } \\
\text { sign }\end{array}$ & Coefficient & $\begin{array}{l}\text { Std. } \\
\text { error }\end{array}$ & $\begin{array}{c}\mathrm{p}- \\
\text { value }\end{array}$ \\
\hline Constant & & $2.200^{-* * *}$ & 0.545 & 0.000 \\
\hline Proklim & + & $0.401 * *$ & 0.154 & 0.010 \\
\hline Farmer education & + & 0.030 & 0.023 & 0.193 \\
\hline Farming experience & + & $0.008 *$ & 0.004 & 0.069 \\
\hline Land area & + & $0.293 * * *$ & 0.034 & 0.000 \\
\hline Own land & - & 0.097 & 0.154 & 0.530 \\
\hline Rental land & $+/-$ & 0.180 & 0.295 & 0.543 \\
\hline Harvest failure & + & 0.095 & 0.158 & 0.551 \\
\hline Membership in farmers group & + & $0.365 * *$ & 0.164 & 0.028 \\
\hline Weather information & + & $0.405 * *$ & 0.161 & 0.013 \\
\hline Awareness about climate change & + & $0.014^{* *}$ & 0.007 & 0.038 \\
\hline $\begin{array}{l}\text { Perception of the risks of climate } \\
\text { change }\end{array}$ & + & $0.016^{* *}$ & 0.006 & 0.012 \\
\hline $\begin{array}{r}\text { Number of observations } \\
\text { Prob }>\text { chi2 } \\
\text { McFadden's Pseudo R2 }\end{array}$ & $\begin{array}{l}112 \\
0.0000 \\
0.2789\end{array}$ & & & \\
\hline
\end{tabular}

${ }^{* * *}$ : Significant at $1 \%$ (p-value $\left.<0.01\right) ;{ }^{* *}$ : Significant at $5 \%(\mathrm{p}$-value $<0.05) ;{ }^{*}$ : Significant at $10 \%$ (p-value $<0.1$ )

Source: Analysis of primary data, 2020 
Farmers were more likely to implement adaptation strategies using short duration varieties (75\% farmers), then crop rotation strategies (64.29\% farmers), ameliorant (33.04\% farmers), and bore well (11.61\% farmers).

The average adaptation strategy implemented by farmers from the Proklim location shows a greater number of strategies compared to non-

Proklim farmers with a difference of 0.2 adaptation strategies, it means that the number of adaptation strategies implemented by farmers in the Proklim location was higher compared to that of farmers from non-Proklim locations.

\section{Factors that influence the implementation of climate change adaptation strategies}

This study examines the factors that influence the number of implementation of climate change adaptation strategies. The dependent variable is the number of adaptation strategies with a lower threshold value of 0 strategies (not implementing the adaptation strategies) and an upper threshold value of 4 adaptation strategies. Table 4 shows the results of tobit analysis using STATA 14. The results show that the Pseudo Rsquare value of 0.2789 , which means that the independent variables tested were able to explain the factors that could influence the number of adaptation strategies applied by $27.89 \%$, while $72.11 \%$ were explained by variables outside the model.

Analysis of the Proklim variable shows a significant positive sign which means that farmers from the Proklim location implemented more adaptation strategies than farmers from nonProklim locations. These results are consistent with the Proklim's goal, which is to increase the community's adaptation capacity for climate change. According to Muttaqin et al. (2019), the Proklim was established because climate change had a negative impact on the economic sector in Indonesia.

Proklim is expected to provide benefits to the community, especially in increasing understanding and application of climate change adaptation and mitigation strategies. Hasan \& Kumar (2019) compared the application of adaptation strategies based on participation in the field school program, the results show that farmers involving in the field school program implemented more adaptation strategies than farmers who did not participate. Another program, Climate Smart Village (CSV), is carried out to increase adaptation capacity, especially in the agricultural sector (Aggarwal et al., 2018). Communities in the Proklim location jointly fight climate change through adaptation and mitigation actions. The community planted trees as a form of mitigation action and forming biopores (water infiltration) as an adaptation action also had an impact on the adoption of adaptation strategies in the agricultural sector. Beginning with an awareness of climate change adaptation and mitigation actions, farmers from Proklim locations will also implement climate change adaptation strategies in the agricultural sector.

The variable farming experience had a significant positive effect, indicating that increasing farming experience will increase the number of 
climate change adaptation strategies. Farmers with long experience know climate indicator changes, their impacts, and actions to minimize the impacts of climate change. In fact, farmers who did not apply the adaptation strategy showed the lowest average experience of 31 years, while farmers who implemented 1 and 2 adaptation strategies showed an average experience of 30 and 31 years. Farmers with the implementation of strategies 3 and 4 adaptation strategies had the highest average rice farming experience of 35 years. These results are consistent with previous research that farming experience has a significant positive effect on the adoption of adaptation strategies. According to Afroz \& Akhtar (2017), farmers with higher experience show a longer cultivation period, so that they have higher knowledge about climate change and how to minimize the impacts. Fadina \& Barjolle (2018) reported that, the higher the experience of farmers, the ability to predict the weather was also higher, then it would increase the possibility of implementing adaptation strategies.

Land area shows a significant positive effect on the number of climate change adaptation strategies. It shows that increasing the area of farmers' cultivation land will increase the number of adaptation strategies. In this study, the average farmer rice land that did not implement the adaptation strategy was $0.11 \mathrm{Ha}$, while the average rice farmer land with the implementation of 4 adaptation strategies was 0.85 Ha. Farmers with larger land areas tent to adopt more adaptation strategies such as using bore well that require a larger area because the area of land is also related to investment from farmers. The more land planted with rice, farmers must invest more by implementing more adaptation strategies. According to Ali \& Erenstein (2017), the reason for this positive effect is because farmers with larger land areas had higher investment opportunities to implement adaptation strategies to minimize the risks of climate change. Afroz \& Akhtar (2017) argue that farmers with large land area will spend more money to implement the adaptation strategy, while farmers with small land area cannot afford to spend the money, so they tend not to implement the adaptation strategy.

The significant positive effect of membership in the farmers group means that farmers who are members of the farmers group implement more adaptation strategies than farmers who are not members of the farmers group. Based on farmers' information, through farmers group meetings they could obtain information about suitable rice varieties to be planted, planting schedules to adjust the arrival of the rainy season, and discussions on how to deal with pests and plant diseases. Participation in farmers group will become social capital to interact with other farmers by discussing phenomena and problems related to agriculture. This will increase knowledge, innovation, and technology to solve problems in agriculture, especially the risks of climate change by implementing adaptation strategies (Gc \& Yeo, 2019; Uddin et al., 2014; Žurovec \& Vedeld, 2019). Farmers who are members of farmers group will get new knowledge 
from the Agricultural Extension Officer. Agricultural extension agents play an important role in conveying new technological information including how to adapt to climate change, so that access has the opportunity to increase the opportunities for implementation of adaptation strategies (Afroz \& Akhtar, 2017; Fagariba et al., 2018).

Weather information had a significant positive effect on the number of adaptation strategies. The results show that farmers who did not receive weather information applied a lower average adaptation strategy (1.41 strategies) than farmers who received weather information (2.02 strategies). Most farmers interviewed received weather forecast information from television. Weather information is useful for farmers to plan adaptation actions that must be taken in the coming planting season. The results are consistent with the research conducted by Fagariba et al. (2018), farmers who regularly obtain weather information show a greater likelihood of implementing adaptation strategies than farmers who don't obtain weather information. Access to weather information is useful for farmers, because it can provide weather forecasts for the upcoming planting season. Accordingly, farmers can plan future planting strategies and implement adaptation strategies to minimize the impact of temperature anomalies, drought, and resurgence of pests and plant diseases.

Awareness of climate change had a significant positive effect on the number of adaptation strategies implemented. Farmers with the implementation of 4 adaptation strategies show the highest level of awareness, which was $68.24 \%$, then followed by farmers who implemented 3 adaptation strategies with an awareness value of $65.33 \%$. The average awareness of farmers who did not implement the adaptation strategy was $57.7 \%$. This shows that farmers with high awareness tent to implement more adaptation strategies. Hasan \& Kumar (2019) obtained the result that awareness of the phenomenon and vulnerability of climate change is positively correlated with the adoption of adaptation strategies. Farmers with higher awareness and understanding of climate change also had higher levels of implementation of adaptation strategies. Farmers are aware that there has been an increase in current temperatures compared to that of 20 years ago. According to Fagariba et al. (2018), increasing temperatures will cause evaporation of ground water which will reduce the water content and moisture in the soil. Farmers will implement an adaptation strategy if rising temperatures is believed to cause crop failure.

Farmers' perceptions of the risks of climate change encourage farmers to implement adaptation strategies. Field studies show that farmers who don't implement adaptation strategies show the lowest average risk perception of $67.24 \%$, while farmers with the adoption of 4 adaptation strategies show the highest average risk perception of $85.76 \%$. Farmers believe that extreme climate events such as floods, droughts, storms cause damage to humans. Therefore, losses can be minimized by implementing adaptation 
strategies. These results are consistent with the research of Azadi et al. (2019) which states that farmers will do the prevention and adaptation to climate change when farmers are given an explanation of the risks or negative impacts caused by climate change on agriculture, property, health and others. Mase et al. (2017) argue that one of the factors influencing the adoption of adaptation strategies is farmers' awareness of extreme climate risks such as drought, extreme weather, and pest and disease outbreaks. Policy makers must take part in increasing the implementation of adaptation strategies, in addition to design programs in increasing the adoption of adaptation strategies, it is also important to know farmers' perceptions of the negative impacts of climate change (Menapace et al., 2015).

\section{CONCLUSION AND SUGGESTION}

Based on the results of the analysis and discussion, it can be concluded that according to the 4 adaptation strategies studied (crop rotation, bore well, short duration rice varieties, and use of calcium fertilizers), there were $87.5 \%$ of farmers who implemented at least 1 adaptation strategy, and $12.5 \%$ farmers did not implement the adaptation strategy. Farmers from Proklim have an average number of adaptation strategies higher than farmers from non-Proklim. Farming experience, land area, membership in farmers group, weather information, awareness of climate change, and perceptions of climate change risks were found to be determinants of increasing the number of adaptation strategies by farmers. In addition, the status of the Proklim location also plays an important role in increasing the number of adaptation strategies because it is known that farmers from Proklim apply a higher adaptation strategy compared to nonProklim farmers.

Suggestions for policy makers and further researchers are as follows. The government needs to pay attention to factors that have a positive effect on increasing the number of adaptation strategies. Access to weather information including weather forecasts for the next growing season must be provided and easily accessible to all farmers. The government must encourage farmers to enter the farmers group to get the latest information on agricultural issues. Farmers' awareness of the phenomenon of climate change and perceptions of the risks posed must be increased through the provision of knowledge about climate change by agricultural extension workers. The positive influence of the Proklim location shows that the existence of the program is able to improve the implementation of climate change adaptation strategies. Proklim needs to be applied in areas that are vulnerable to the negative impacts of climate change so farmers can increase the implementation of adaptation strategies. Suggestions for further researchers to examine the impact of the implementation of adaptation strategies on the productivity and income of farmers in Proklim and non-Proklim locations. It is also necessary to expand the research location to obtain more detailed results.

\section{ACKNOWLEDGMENT}


The author would like to thank the Deputy for Strengthening Research and Development, Ministry of Research and Technology/National Research and Innovation Agency who has provided financial support for research and publication activities that the author undertakes.

\section{REFERENCES}

Abid, M., Schneider, U. A., \& Scheffran, J. (2016). Adaptation to climate change and its impacts on food productivity and crop income: Perspectives of farmers in Rural Pakistan. Journal of Rural Studies, 47(2016), 254-266. https://doi.org/10.1016/j.jrurstu d.2016.08.005

Afroz, R., \& Akhtar, R. (2017). Determinants of Malaysian Farmers' Choice of Adaptation Strategies for Adapting to Climate Change in Kedah Malaysia. Asian Journal of Agricultural Research, 11(4), 120-127. https://doi.org/10.3923/ajar.201 7.120.127

Aggarwal, P. K., Jarvis, A., Campbell, B. M., Zougmoré, R. B., KhatriChhetri, A., Vermeulen, S. J., Loboguerrero, A. M., Sebastian, L. S., Kinyangi, J., Bonilla-Findji, O., Radeny, M., Recha, J., MartinezBaron, D., Ramirez-Villegas, J., Huyer, S., Thornton, P., Wollenberg, E., Hansen, J., AlvarezToro, P., ... Yen, B. T. (2018). The climate-smart village approach: Framework of an integrative strategy for scaling up adaptation options in agriculture. Ecology and Society, 23(1), 1-14. https://doi.org/10.5751/ES09844-230114

Aldrian, E., Karmini, M., \& Budiman. (2011). Adaptasi dan Mitigasi Perubahan Iklim di Indonesia. Pusat Perubahan Iklim dan
Kualitas Udara, Badan Meteorologi, Klimatologi, dan Geofisika (BMKG).

Ali, A., \& Erenstein, O. (2017). Assessing farmer use of climate change adaptation practices and impacts on food security and poverty in Pakistan. Climate Risk Management, 16(2017), 183-194. https://doi.org/10.1016/j.crm.20 16.12.001

Azadi, Y., Yazdanpanah, M., \& Mahmoudi, H. (2019). Understanding smallholder farmers' adaptation behaviors through climate change beliefs, risk perception, trust, and psychological distance: Evidence from wheat growers in Iran. Journal of Environmental Management, 250(2019), 1-9. https://doi.org/10.1016/j.jenvma n.2019.109456

Bacha, M. S., Nafees, M., \& Adnan, S. (2018). Farmers perceptions about climate change vulnerabilities and their adaptation measures in District Swat. Sarhad Journal of Agriculture, 34(1), 1-16. https://doi.org/10.17582/journal. sja/2018/34.2.311.326

BPS Sleman. (2019). Kabupaten Sleman Dalam Angka 2019. BPS Kabupaten Sleman.

Fadina, A., \& Barjolle, D. (2018). Farmers' adaptation strategies to climate change and their implications in the Zou Department of South Benin. Environments, 5(15), 1-17. https://doi.org/10.3390/environ ments5010015

Fagariba, C., Song, S., \& Soule Baoro, S. (2018). Climate change adaptation strategies and constraints in Northern Ghana: Evidence of farmers in Sissala West District. Sustainability, 10(1484), 1-18. 
Agro Ekonomi Vol.31/Issue.2, December 2020

https://doi.org/10.3390/su10051 484

Gc, A., \& Yeo, J.-H. (2019). Perception to adaptation of climate change in Nepal: An empirical analysis using multivariate probit model. Sci, 1(12),

1-14. https://doi.org/10.3390/sci1010 012.v1

Greene, W. H. (2012). Econometric Analysis: Seventh Edition (7th ed). Prentice Hall.

Gunawati, D., \& Rejekiningsih, T. (2020). Building Ecological Citizens Through the Implementation of Climate Village Programs as Climate Change Mitigation Effort. Proceedings of the $3 r d$ International Conference on Learning Innovation and Quality Education (ICLIQE 2019), 397, 1124-1131.

https://doi.org/10.2991/assehr.k. 200129.139

Hasan, M. K., \& Kumar, L. (2019). Comparison between meteorological data and farmer perceptions of climate change and vulnerability in relation to adaptation. Journal of Environmental Management, 237, 54-62.

https://doi.org/10.1016/j.jenvma n.2019.02.028

IPCC. (2014). Climate Change 2014: Synthesis Report. Intergovernmental Panel on Climate Change.

Irham, Saito, O., Mohri, H., Wirakusuma, G., Rohmah, F., \& Perwitasari, H. (2018). Traditional Farmers' Adaptation Strategies on Climate Change of Different Environmental Conditions in Yogyakarta Province, Indonesia. In K. Takeuchi, O. Saito, H. Matsuda, \& G. Mohan (Eds.), Resilient Asia (pp. 81-94). Springer Japan. https://doi.org/10.1007/978-4431-56597-0_5

Khanal, S., Mandal, R. A., \& Nepal, A. (2019). Assessing Effectiveness of Climate Smart Activities: A Study from Rural Areas, Nepal. Agricultural Research \& Technology: Open Access Journal, 20(1)

https://doi.org/10.19080/ARTOA J.2018.19.556114

Mase, A. S., Gramig, B. M., \& Prokopy, L. S. (2017). Climate change beliefs, risk perceptions, and adaptation behavior among Midwestern U.S. crop farmers. Climate Risk Management, 15(2017), 8-17. https://doi.org/10.1016/j.crm.20 16.11.004

Measey, M. (2010). Indonesia: A Vulnerable Country in the Face of Climate Change. Global Majority EJournal, 1(1), 31-45.

Menapace, L., Colson, G., \& Raffaelli, R. (2015). Climate change beliefs and perceptions of agricultural risks: An application of the exchangeability method. Global Environmental Change, 35(2015), 70-81.

https://doi.org/10.1016/j.gloenvc ha.2015.07.005

Muslim, C. (2013). Mitigasi perubahan iklim dalam mempertahankan produktivitas tanah padi sawah (Studi kasus di Kabupaten Indramayu). Jurnal Penelitian Pertanian Terapan, 13(3), 211222.

Muttaqin, Z., Yulianti, A., \& Karmanah. (2019). Climate village program (ProKlim) in Simurugul SubVillage, Margawati Village, Garut Kota Sub-Regency, Garut Regency, West Java Province, Indonesia. IOP Conference Series: Earth and Environmental Science, 299, 1-17. https://doi.org/10.1088/17551315/299/1/012046 
Nazir, Moh. (2017). Metode Penelitian. Ghalia Indonesia.

Niles, M. T., Lubell, M., \& Brown, M. (2015). How limiting factors drive agricultural adaptation to climate change. Agriculture, Ecosystems \& Environment, 200, 178-185. https://doi.org/10.1016/j.agee.20 14.11.010

Sappaile, B. I. (2007). Pembobotan butir pernyataan dalam bentuk skala likert dengan pendekatan distribusi z. Jurnal Pendidikan dan Kebudayaan, 064, 126-135.

Trinh, T. Q., Rañola, R. F., Camacho, L. D., \& Simelton, E. (2018). Determinants of farmers' adaptation to climate change in agricultural production in the central region of Vietnam. Land Use Policy, 70(2018), 224-231. https://doi.org/10.1016/j.landuse pol.2017.10.023

Uddin, M., Bokelmann, W., \& Entsminger, J. (2014). Factors affecting farmers' adaptation strategies to environmental degradation and climate change effects: A farm level study in Bangladesh. Climate, 2(2014), 223-241. https://doi.org/10.3390/cli20402 23

Waibel, H., Pahlisch, T. H., \& Völker, M. (2017). Farmers' perceptions of and adaptations to climate change in Southeast Asia: The case study from Thailand and Vietnam. In Climate Smart Agriculture: Building Resilience to Climate Change (1st edition, Vol. 52). Springer Nature.

Widada, A. W., Hardyastuti, S., Mulyo, J. H., \& Irham, I. (2014). Analisis kerentanan penghidupan rumah tangga tani akibat perubahan iklim di Kabupaten Gunungkidul. Agro Ekonomi, 24(1), 10-24. https://doi.org/10.22146/agroek onomi.17356

WMO. (2017). Indicators of Climate Change. World Meteorological Organization.

Žurovec, O., \& Vedeld, P. O. (2019). Rural livelihoods and climate change adaptation in Laggard Transitional Economies: A Case from Bosnia and Herzegovina. Sustainability, 11(6079), 1-27. https://doi.org/10.3390/su11216 079 